\title{
A MAGYARORSZÁG ÉS ROMÁNIA KÖZÖTTI VASÚTI SZEMÉLYSZÁLLÍTÁSI KAPCSOLATOK TÖRTÉNETI ÁTTEKINTÉSE
}

\author{
ERDEINÉ KÉSMÁRKI-GALLY SZILVIA - ERDEI ATTILA \\ - NESZMÉLYI GYÖRGY IVÁN
}

REGIONAL ASPECTS OF RAILWAY PASSENGER TRANSPORT BETWEEN HUNGARY AND ROMANIA

\begin{abstract}
The main function of public transport systems is the mobility which contributes to the competitiveness and to the appropriate quality of life and cohesion of the society. The main actors of the transportation systems are the passengers, the suppliers of services and the decision-making authorities and organizations (like the government, local governments and the professional authorities). In the present study, the authors provide thorough insight into the state of passenger rail transport between Hungary and Romania, including the possibilities for development in the future. The study is a historical overview based on international and domestic secondary research results. In selecting the literature, we processed regional railway transport and transport history secondary sources. According to the research, in both countries, railways continue to play a significant role in passenger transport. The maintenance of rail traffic between countries requires the cooperation of neighbouring states. Fares and services should be attractive and simple. This is especially true if different languages and different currencies are used on both sides of the border. The development of cross-border traffic can bring important benefits to both larger and smaller regions (e.g. labour market, investment, etc.). In this light, the modernization of the infrastructure and the vehicle fleet in line with the expectations of the 21 st century is important.
\end{abstract}

Keywords: Connection, Hungary, Railway, Romania, Transport

\section{Bevezetés}

Magyarország és Románia kapcsolatát - a nehéz történelmi örökség ellenére, vagy éppen azzal együtt - sok tekintetben az egymásra utaltság jellemzi. A két ország gazdasági együttmúködése, azon belül a kétoldalú árucsereforgalom erôteljes, Románia Magyarország egyik legfontosabb exportpiaca. Számos magyar vállalat befektetőként is jelen van Romániában, mindamellett, különösen 2010 óta a magyar kormány kiemelt figyelmet biztosít - beleértve az állampolgárság megszerzésének lehetôségét is - a romániai magyarság számára. A trianoni békeszerződést követő száz év alatt a két ország kapcsolatát alapvetően a bizalom hiánya jellemezte mindkét oldalról, ami erôteljesen kitapintható volt - többek között - a kétoldalú vasúti összeköttetés fejlesztésének elmaradásában. Az utóbbi évtizedekben azonban, az EU tagjaként, különösen, ha Románia is csatlakozik a Schengeni övezethez, a két ország előtt egyre inkább esély nyílhat a kapcsolatok fejlesztésének win-win típusú megközelítésére. Tény, hogy akár üzleti, akár magáncélú kapcsolat motiválja, mindkét ország polgárai részéről igény van az utazási lehetőségek számottevő javítására. A romániai magyarság és azt anyaország kapcsolata az utóbbi száz évben soha nem volt annyira mentes a formális akadályoktól, mint napjainkban. Erdélyi, partiumi fiatalok rendszeresen járnak Magyarországra, sokan nálunk tanulnak és vállalnak munkát, míg a Romániába, különösen Erdély egyes részeibe irányuló magyar beutazó forgalom is számottevő. 
A két ország településeit összekapcsoló közlekedési infrastruktúra fejlesztésének szükségessége nyilvánvaló. A vasút ráadásul fáziskésésben is van, hiszen a közúti fejlesztések - igaz nem túl gyors ütemben - már több helyen is folyamatban vannak (pl. a 43. sz. foút autópályává fejlesztése és összekötése az Arad-Temesvár irányában épülő részben már elkészült pályaszakasszal, továbbá az épülő M4 autópálya, valamint a kivitelezés alatt álló észak-erdélyi autópálya belátható időn belüli összekapcsolása). A mainál számottevően gyorsabb, kényelmesebb, de megfizethető modern vasúti összeköttetés mindenképpen vonzó alternatívát jelenthet sokaknak a gépkocsi használatával szemben.

Mind Magyarország (2004. május 1-jétől), mind Románia (2007. január 1-jétől) tagja az Európai Uniónak, ami a vámellenőrzés megszűnését és a határellenőrzés jelentős egyszerűsödését vonta maga után. A közösségi közlekedési kapcsolatok ennek ellenére a legtöbb helyen nem, vagy alig fejlődtek. Románia közeljövőben várható csatlakozása a Schengeni övezethez a mai határátkelőhelyeken túl további új kapcsolatokat tud megnyitni, elsôsorban a közúti határátkelési lehetőségek között, de a vasúti lehetőségek mellett sem szabad szó nélkül elmenni. Munkánk célja a Magyarország és Románia közötti vasúti személyszállítás jelenlegi helyzetének ismertetése, valamint a kötöttpályás személyszállítás fejlesztési vonalainak vizsgálata és javaslatok megfogalmazása. Cikkünkben foglalkozunk a magyarországi és a romániai vasúti közlekedés rövid történetével, majd a két szomszédos ország közötti egykori és jelenlegi vasútvonalakkal, illetve az európai TEN-T törzshálózat magyarországi és romániai hálózati folyosóinak regionális jelentőségével.

A magyar és a román vasúthálózat történetének áttekintése után megvizsgáltuk a múltbeli és a jelenlegi nemzetközi vasúti összeköttetéseket a két új ország között. HAJDú Z. (2019) könyvében kiemeli, hogy a rendszerváltozás után a két ország számára a határtérség fejlesztésének kiemelt célja a határok átjárhatóságának fejlesztése, ezen belül kiemelt területként fogalmazódott meg az úthálózat és a vasúthálózat nagyarányú fejlesztésének igénye. A határokon átnyúló infrastruktúra, ezen belül különösen a vasúti személyszállítás fejlesztésével, problémáival, történelmével foglakozó széleskörű hazai és nemzetközi irodalom áll rendelkezésre. A szerzők célja az említett szekunder források felhasználásával összefoglaló áttekintést nyújtani a távolsági és a határokon átnyúló vasúti személyszállítás újjáélesztésének lehetséges fejlesztési koncepcióiról. A szakirodalmak kiválasztásánál a szerzők elsősorban a regionális, vasúti közlekedési és közlekedéstörténeti szekunder forrásokat dolgozták fel. A tanulmány fő kérdése, hogy magyar és román vasút múltjáról és jelenéről szóló történeti áttekintés révén milyen következtetések javaslatok fogalmazhatók meg a vasúti közlekedés kétoldalú kapcsolatainak jövőjére vonatkozóan.

\section{A magyarországi vasúti közlekedés rövid története}

Az első magyarországi vasútvonal (Pest-Vác) 1846-os átadása óta eltelt közel 175 év alatt, a folyamatosan bővülő magyar vasúthálózat képes volt betölteni az iparosodó társadalom igényeit, közben mintegy motorját képezte a korabeli fejlődésnek.

A Magyar Államvasutak (MÁV) Magyarország egyik legpatinásabb közlekedési vállalata. Az 1867-es kiegyezést követóen az állam mind jelentősebb szerepet vállalt a vasúthálózat fejlesztésében, ehhez pedig felhatalmazást kért és kapott jelentős mértékú, a vasút fejlesztésére fordítható államkölcsön felvételére. Ez a jelentős pénzügyi keret tette lehetôvé az állam számára, hogy felvásárolja a csődbe ment Cs. Kir. szabadalmazott Magyar Éjszaki Vasúttársaságot és az általa épített Pest-Hatvan-Losonc-Selmecbánya vasútvonalat. A Közmunka- és Közlekedési Minisztérium 1869-ben úgy döntött, hogy az állami tulajdonba vett vasútvonal és a hamarosan átadandó Zákány-Zágráb vonal neve Magyar 
Királyi Államvasutak legyen. Ezt az évet tekintjük a MÁV alapítási évének, és a megvásárolt vonal lett a MÁV első vasútvonala. Az első (magántőkéből épült) vasútvonalat $(33 \mathrm{~km})$ hamarosan követte a Pest-Szolnok vasút megépítése.

A magyar vasút I. világháborúig terjedő korszaka szerencsésen egybeesett az országnak az európai gazdasági rendszerbe való intenzív beintegrálódásával és a vasúti szállításnak, mint fejlődésben lévő szállítási ágazatnak nemzetközi viszonylatban is meghatározó, fellendülésben lévő ütemével. Ebben az időszakban az ország, az egyes régiók és települések gazdasági fellendülésének egyik alapfeltétele volt a megfelelő vasúthálózat kiépítése, illetve a vasúti kapcsolat létesítése. Ennek az igénynek megfelelően néhány évtized leforgása alatt jött létre a nyugati országok vasúthálózatához felzárkózó magyar vasúthálózat (KöLLER L. 2003). A magyar vasúthálózat legnagyobb kiterjedését az I. világháború kezdetére érte el, ekkor a Magyar Királyság Európa második legsúrúbb vasúthálózatával rendelkezett (MAJDÁN J.2010). Baross Gábor közlekedéspolitikai koncepciójának köszönhetően a vasút turisztikai funkciója is kidomborodott, hiszen az új tarifapolitika nemcsak általában véve tette elérhetővé mindenki számára a vasúti utazást, hanem például a fürdő- és nyaralóhelyek elérését is olcsóbbá tette (HoRvátH Cs. S. 2016).

Az első világháború során a hadiszállítás egyik legfontosabb szereplője a vasút volt, amelyrôl elmondhatjuk, hogy ennek a fontos stratégiai szerepnek lett ,áldozata”. A padovai fegyverszünet és a Trianoni békekötés közti időszakban a kisantant (Csehszlovákia, Románia, Szerb-Horvát-Szlovén Királyság) országainak politikusai mind-mind szemük előtt tartották a vasúti pályák és a gördülőanyag jelentős részének megszerzését (MAJDÁN J. 2001).

Az I. világháborút követő területi változások jelentős hatást gyakoroltak a társaság életére, és a pókhálóhoz hasonló, az eredeti, a Kárpát medence természetes térszerkezetéhez illeszkedő vonalrendszer szétesett. Az első világháború előtt a Magyar Királyságnak - mivel nyugaton, északon és északkeleten a Monarchiával volt határos - csupán öt országhatára és négy vasúti határállomása volt idegen államok (Románia, Szerbia) vasútjaival. Az új határok 49 vasútvonalat vágtak át, melyek közül 42 esetében katonai, stratégiai okokból nyílt vonalon húzták meg a határvonalat. Ezzel elszakították egymástól a nagyvárosokat - vasúti csomópontokat - és mezőgazdasági környezetüket (MISZLAY Zs. 2009). A magyar-román határ menti nagyvárosok HARDI és szerzőtársai (2009) szerint tulajdonképpen a történelmi Partium és a délebbre fekvő Bánát városait jelentik, amelyek a történelmi Magyarország alföldi városainak azon tagjai voltak, amelyek Erdély felé láttak el közvetítő szerepet. Ez nyomon követhetjük Debrecen példáján keresztül is. A korábbi jól múködő, kiterjedt gravitációs zónával rendelkező város egyik pillanatról a másikra az ország perifériáján találta magát, gazdasági, kulturális és emberi kapcsolatai elvesztek (SÜLI-ZAKAR I.-KECSKÉS T. 2015).

A magyar vasúthálózat az európai fejlődést követve jött létre és a II. világháború időszakáig többé-kevésbé lépést tudott tartani a múszaki fejlődéssel (hálózatsűrúség, kétvágányú vonalak aránya, villamosított vonalak aránya, pályára engedélyezett sebesség, hézagnélküli felépítmény aránya, nagytömegú sínek aránya, állomások száma, szintbéli útátjárók, mútárgyak, biztosítóberendezés, jármúvek stb.).

Jelenleg a tömegközlekedés aránya nemzetközi összehasonlításban még kedvezőnek mondható, de a rendszerváltozást követő évtizedekben a társadalmi, gazdasági folyamatok, valamint a rendszeresen elmaradó infrastruktúrafejlesztés miatt a magyar vasútnál piacvesztés következett be. A hazai személyszállítási adatokban folyamatos csökkenés tapasztalható az 1970-es évektől, a motorizáció fejlődésével a vasút fokozatosan kiszorult a hagyományos közlekedési piacról. Az 1990-es évektől a piacgazdaság megjelenésével, a korábban mesterségesen fenntartott gazdasági környezetben lévő vasút összeomlott, mivel a vasúti közlekedést érintő kedvezőtlen hatások egyszerre, egyidejúleg, ,,sokksze- 
rúen” érvényesültek (TóTH G. et al. 2012). Mindezek a vasúti személy- és áruszállítási teljesítmények visszaeséséhez vezettek (TóTH G. ET AL. 2014). A 2010-es év mélypontja után a fejlesztések és vasútfelújítások hatására a visszaesés megállt, sőt az elmúlt 10 évben mintegy 10 millió fővel növekedett az utasok száma. Az elmúlt évek csökkenő utasszám tendenciája 2017-ben megfordult, és jelenleg meghaladja az évi 140 millió utast.

Napjainkban a MÁV-csoport Magyarország legnagyobb, legfontosabb kötöttpályás közlekedési szolgáltatója. A cégcsoport 30 tag vállalatának feladatai közé tartozik többek között a pályahálózat üzemeltetése, a személyszállítás, a vontatás, a karbantartás, illetve a jármúgyártás. A MÁV-csoport kb. 38000 munkavállalót foglalkoztat. 2007. július 1-jén alakult meg a személyszállító leányvállalat, a MÁV-START Zrt. 2014-ben összevonásra került a szintén 2007-ben kialakított MÁV-Gépészet Zrt., a MÁV-Trakció Zrt., és a MÁV-START Zrt. Az új társaság neve MÁV-START Zrt. lett, mely a vontatás és gépészeti képességet is magába integrált vállalatként múködik. A magyarországi vasúti személyszállítás forgalmának 85\% -át a MÁV-START Zrt. bonyolítja (SomogYi B.-Michalkó G. 2016). A MÁVSTART Zrt. az egyetlen európai vasúttársaság, amelyik saját jármúgyártási képességgel rendelkezik!

A MÁV-START Zrt. a hazai 7273 km-es vasúthálózaton összesen 1344 ponton (pályaudvar, vasútállomás, megállóhely) szolgálja ki az utasokat, napi több ezer járattal. A vállalat fő feladata a közszolgáltatási személyszállítás. Szolgáltatási tevékenységét 1863 személykocsi, 467 motorkocsi, 976 (dízel/villamos) mozdony segítségével látja el. Az egyik legnagyobb hazai foglalkoztató, jelenleg több mint 14000 munkavállaló végzi mindennapi feladatként az utasok kiszolgálását.

Az elmúlt évtizedekben végbement változások (például: motorizáció, közlekedés fejlődése, utazási szokások és igények változása, digitalizáció, környezetvédelem stb.) éreztetik környezeti hatásukat, mely a vasút számára is kihívás és reagálnia szükséges. A MÁVSTART Zrt.és a MÁV-csoport a felügyeleti szervekkel, minisztériumokkal együttmúködve a szolgáltatási stratégia három pilléren nyugvó fejlesztésébe kezdett. A fejlesztési stratégia három pillére: menetrendi fejlesztés, jármúfejlesztés, és értékesítés fejlesztés.

Magyarországon napjainkban a másik személyszállítói szolgáltató a Győr-SopronEbenfurti Vasút Zrt. (GYSEV). A vállalat Magyarországon és Ausztriában múködő 434,7 km-es pályahálózatot fenntartó és üzemeltető integrált vasúttársaság. A társaság a nyugat-magyarországi régió vasúti közlekedésében játszik fontos szerepet, kiszolgálja az ausztriai burgerlandi lakosok ingázó forgalmát, bekapcsolja Sopront Bécs irányába, illetve jelentős regionális szerepet lát el Szombathely térségében.

\section{A romániai vasutak történetének rövid áttekintése}

Románia vasúthálózatának hossza 10777 km, amelyből 4029 km villamosított. A hálózat összekapcsolódik a páneurópai vasúthálózatokkal, személyszállítási és teherfuvarozási szolgáltatásokat nyújtva más európai országok számára.

A jelenlegi Románia területén az elsố vasútvonalat 1854-ben nyitották meg. Ez a Bánságban lévő Oravicabánya (Oravița) és a Duna egyik kikötője, Báziás (Baziaş) között haladt. A vasútvonal építésének fő célja a Bánság szénbányáiban (Stájerlakanina és környéke) kitermelt szén elszállítása volt. A Bukarest-Gyurgyevó (Giurgiu) vonal volt az első vasút, amelyet az akkori Román Királyság területén építettek. A vonal építését az angol John Trevor-Barkley cég végezte 1865 és 1869 között.

1866-ban a német Strousberg konzorciumi szerződést kötött egy 915 km hosszú vasútvonal építésére Varcsaró településtől (Vârciorova) a Román Királyság északi részen elhe- 
lyezkedő Románvásár (Roman) városáig, Pitești, Bukarest, Bodzavásár (Buzău), Brajla (Brăila), Galac (Galați) és Tekucs (Tecuci) városokon keresztül. Ezt a fontos vasútvonalat különböző szakaszokban nyitották meg. Az elsô szakasz 1872-ben nyílt meg [PiteștiBukarest-Galac (Galați)-Románvásár (Roman)], míg a Varcsaró-Pitești rész 1878-ban nyílt meg. 1880 januárjában a román parlament megszavazta a Varcsaró-Románvásár vonal tulajdonjogának állami tulajdonba vételét, a Căile Ferate Române (CFR) igazgatása alatt. 1889-re a vasútvonalak teljes hossza elérte az 1377 km-t. A román állam volt a Román Királyság összes vasútvonalának tulajdonosa.

1918-ban a Román Királyság, Erdély, Bánság, Besszarábia és Bukovina történelmi régiói egyesültek. A korábban Ausztria-Magyarország és az Orosz Birodalom területén fekvő vasútvonalak a CFR igazgatása alá kerültek. A Besszarábia területén levő vasútvonalaknál szükség volt a vonalak átépítésére, mivel az Oroszországban a nyomtáv szélesebb volt, mint a román ún. normál nyomtávú vasutaknál (TURNOCK, D. 2004). A kisantant szövetséges államok számára stratégiailag fontos volt, hogy közvetlen vasúti kapcsolat jöjjön létre köztük, ezért 1924-ben elkészült a Nadab és Nagyszalonta közötti 35 km-es vonalszakasz, amely biztosította a közvetlen összeköttetést Jugoszlávia, Románia és Csehszlovákia között.

A második bécsi döntés 1940 őszén visszacsatolta az észak-erdélyi területeket Magyarországhoz. Az új határok kialakítása miatt azonban Székelyföld nem volt vasúton elérhető. A megoldást a Szeretfalva (Sărățel)-Déda közötti 48 km hosszúságú vonal építése jelentette, amelyet 1942-ben adtak át a forgalomnak. A II. világháború vége után a békeszerződés következtében az észak-erdélyi terület újra román fennhatóság alá került, összes vasútvonala a CFR tulajdonába került.

1947 után, mint más szocialista országokban, a vasút az állam gyors iparosodásának jelképe volt. Nagyon jelentős mértékű beruházás történt a vasúti infrastruktúrába, mint például különféle új vonalak építése, villamosítás és a vonal kétvágányúsítása (TURNOCK, D. 2005).

Jelenleg hat társaság végez személyszállitó szolgáltatást Romániában (1.táblázat). Az uralkodó szereplő továbbra is a történelmi üzemeltető, mely 1880 óta múködik, a CFR Călători, a Román Nemzeti Vasút (CFR) utasszállító üzletága. Ezen kívül öt további magánkézben levő üzemeltető végez személyszállítási szolgáltatást. Egyrészt a fóvonalakon versenyeznek a CFR Călători szolgáltatásával, másrészt a CFR Infrastructură-tól lízingelt mellékvonalakon vasúti személyszállítási szolgáltatást üzemeltetnek (RAYMOND, G. 2017).

A legnagyobb üzemeltető, a CFR Călători, jelenleg 360 dízel és 365 elektromos mozdonnyal, 216 dízel és 33 elektromos motorvonattal, valamint 2288 személyszállító vagonnal rendelkezik, köztük 227 háló- és 22 étkezőkocsival. A CFR Călători Románia főbb

Személyszállítási szolgáltatók Romániában

1. táblázat-Table 1

Passenger train operators in Romania

\begin{tabular}{lc}
\hline Szolgáltató & Éves vonat-km (millió) \\
\hline CFR Călători (CFR) & 50,3 \\
RegioTrans & 6,0 \\
Transferoviar Călători (TFC) & 3,3 \\
Interregional Călători (IRC) & 1,2 \\
Softrans & 0,7 \\
Astra Trans Carpatic & 2017. februártól üzemel \\
\hline
\end{tabular}

Forrás/Source: RAYMOND, G. 2017 
városai és turisztikai területei között nyújt szolgáltatást. A RegioTrans Románia második legnagyobb utasvonat-üzemeltetôje a CFR Călători után, és a legnagyobb magántulajdonú. A RegioTrans szolgáltatásai elsősorban Brassó, Marosludas (Luduş) / Balázsfalva (Blaj), Temesvár és Arad környékén megtalálhatók. A Transferoviar Călători kilenc útvonalon üzemeltet vasúti személyszállítási szolgáltatásokat, amelyek közül három Bukarest Nord területén végződik. Az Interregional Călători (IRC) személyszállító vonatait a román közlekedési minisztériummal kötött szerződés alapján üzemelteti. A személyszállítási tevékenységet 2007-ben kezdték Vaskoh (Vaşcău), Pusztahollód (Holod) és Illye (Ciumeghiu) közötti útvonalon. A Softrans csak a fővonali CFR hálózaton múködik (Craiova-BukarestConstanța és Craiova-Bukarest-Brassó), nem bérel mellékvonalakat. A vállalat újépítésú ún. Hyperion típusú motorvonatokkal végzi a személyszállítási szolgálatatást. Az Astra Trans Carpatic 2017-től üzemeltet járatokat az Arad-Bukarest-Constanța viszonylatban. A társaság új, román gyártású vasúti kocsikat, illetve Dániából használtan vásárolt motorvonatokat közlekedtet.

Európában általánosan elterjedt gyakorlat, hogy amennyiben egy hatóság egy adott útvonalon személyszállító vonatokat kíván biztosítani, ajánlati felhívást tesz közzé, amelyben meghatározza a szükséges szolgáltatási szinteket. Általánosságban elmondható, hogy a jegybevételek nem fedezik a felmerülő költségeket, ezért a felhívásban vagy az ajánlatokban meghatározzák az állami támogatás mértékét is. Ugyanakkor a román közlekedési minisztérium nem ír ki pályázatot a vasúti személyszállítási szolgáltatásokra. A CFR Infrastructură árveréseket tart, amelyek során a magánvállalatok ajánlatot tehetnek a nem átjárható (non-interoperable) vonal lízingelésére, általában négy éves időtartamra. Ebben az időszakban az üzemeltető nemcsak a járatok üzemeltetéséért, hanem a vonal infrastruktúrájának karbantartásáért is felelős.

Napjainkban, Romániában az egyetemisták számára ingyenessé tett személyszállítást a szolgáltatók vasúti kocsikkal nehezen tudják elégséges minőségi szinten biztosítani. Az elmúlt években a román gazdaság az Európai Unió szempontjából észrevehetô teljesítményt ért el (VASA, L.-RADULESCU, A. 2019).

A beruházások elmaradása miatt a vasúti szolgáltatók nehéz helyzetben vannak, mivel a szolgáltatási színvonaluk az európai normáktól sajnos messze elmarad. Kiemelten fontos ezért az infrastruktúra és a jármúpark minél hamarabb történő 21. századi elvárásoknak megfelelő modernizációja, mely nemcsak a társadalmi-gazdasági elvárások oldaláról merül fel, hanem környezetvédelmi szempontból is.

\section{Vasútvonalak Magyarország és Románia között}

Az alábbi fejezetben röviden bemutatjuk a Magyarország és Románia közötti vasútvonalakat. Az 1. ábra szemlélteti a határon átmenő felhagyott és jelenleg is forgalmat bonyolító vonalakat [lásd 1-12] Magyarország és Románia között.

A Zajta-Nagypeleske (Peleş) határátmenet [lásd: 1] az egykori Fehérgyarmat-ZajtaSzatmárnémeti (Satu Mare) vonalon helyezkedett el. A vonal Szatmárnémeti és Fehérgyarmat közötti szakaszát a Szatmár-Fehérgyarmati HÉV társaság építtette, ezt a szakaszt 1898-ban adták át a forgalomnak. Az 1920-as trianoni békeszerződés a vonalat Zajtánál kettévágta, így a Magyarország területén maradt vonalszakasz minden kapcsolatát elvesztette a magyar vasúthálózat megmaradt részével. A hiányzó Fehérgyarmat-Kocsord-Mátészalka összekötő szakaszt 1926 januárjában adták át a forgalomnak, így megszűnt a vonal szigetüzeme. Észak-Erdély 1940-es visszacsatolásakor a határátmenetet visszaépítették, így 1940 decemberétől négy éven keresztül a vasútvonal is összekapcsolta Mátészalkát (és 


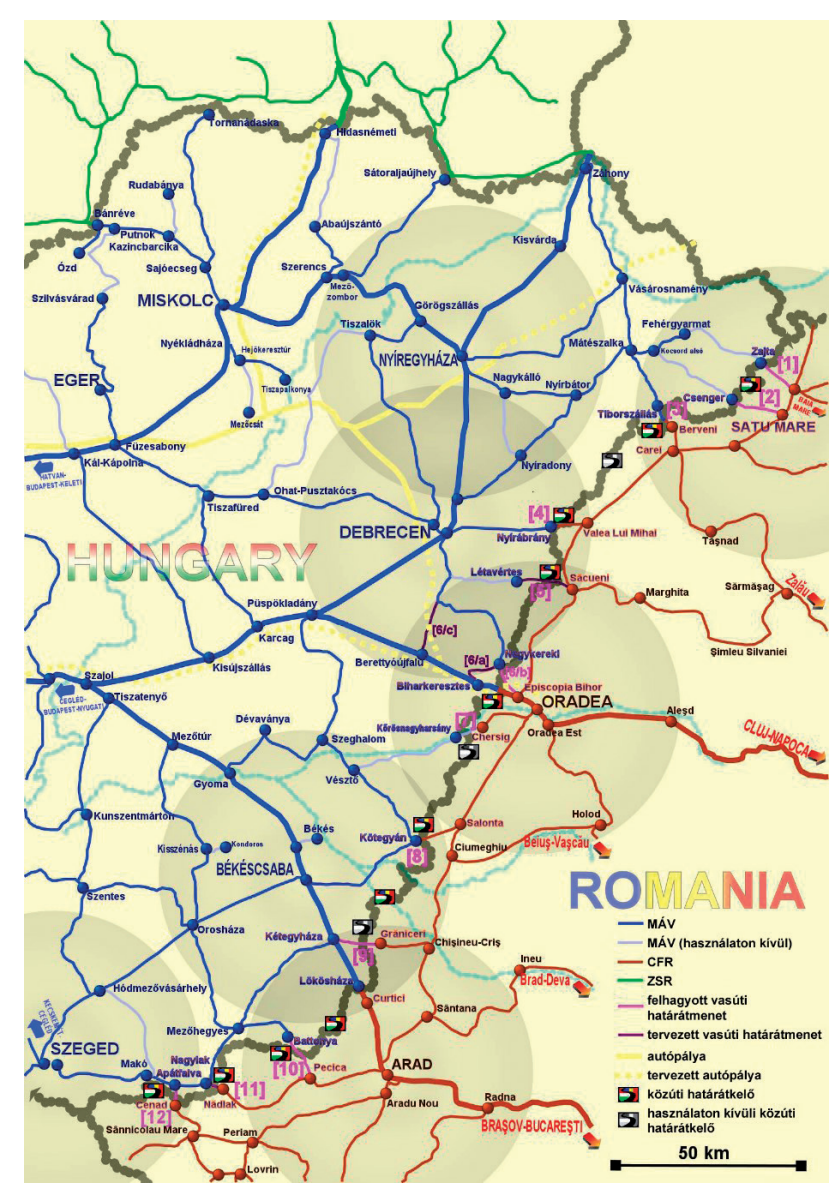

1. ábra A múlt és a jelen határon áthaladó vasútvonalai Magyarország és Románia között Figure 1 Border-crossing railway lines between Hungary and Romanian the past and present Forrás/Source: DRKE 2011

közvetve Nyíregyházát) Szatmárnémetivel. A második világháború után azonban újra felbontották a vasúti kapcsolatokat, amikor Szatmárnémeti visszakerült Romániához. A hiányzó, körülbelül 15 kilométer hosszúságú Zajta-Szatmárnémeti visszaépítése jelentős javulást eredményezne a két megyeszékhely (Nyíregyháza és Szatmárnémeti), illetve az érintett kistérségi központok (Fehérgyarmat, Mátészalka) közötti közösségi közlekedési kapcsolatokban. A vonal a magyarországi szakaszának jelentős mértékű felújítása (100-120 km/h sebességre alkalmasság) után hivatásforgalom lebonyolítására is alkalmas lenne, továbbá lehetőséget biztosítana a magyar, illetve román fóvonalakhoz történő csatlakozásra.

A Csenger-Óvári (Oar) határátmenet [lásd: 2] a Szatmár-Mátészalkai HÉV társaság által 1908-ban épített Szatmárnémeti-Mátészalka vasútvonalon helyezkedett el. Rövid 12 éves múködés után ennek a vonalnak folytonossága is megszakadt a trianoni békediktátum után. A vonal magyarországi végállomása Csenger lett. A román oldalon Óvári lett a végállomás. A második bécsi döntés után 4 évre ez a szakasz ismét a MÁV kezelésébe került. A II. világháború után a határon átmenő szakaszt elbontották. A romániai rövid szakaszt a hetvenes években teljesen elbontották, míg a magyarországi szakaszon jelenleg napi 
két vonatpár közlekedik, ami a hivatásforgalom, munkába, iskolába járás szempontjából semmiképpen nem elégséges. A közeli Csengersima-Pete közúti átkelőn egyre növekvő forgalmának jelentős része átterelhető lenne a vasútra, ha újraépülne a 22 kilométeres (eredeti nyomvonalon) romániai szakasz, illetve felújításra kerülne a magyarországi szakasz, hogy nagyobb sebességre, ütemes menetrendre legyen alkalmas.

Az Ágerdőmajor-Börvely (Berveni) vasúti határátmenet [lásd: 3] a Mátészalka-Tiborszállás-Nagykároly (Carei) vasútvonalon helyezkedik el. Ez a vonal egyike a Magyarország és Románia között jelenleg is múködő öt nemzetközi vonalnak. Az 1905-ben a NagykárolyMátészalka-Csop helyi érdekú vasútként épült vonal sajnos még mindig magán hordozza a mellékvonalak jellemzőit. Mivel az Ágerdőmajor megállóhely a legközelebbi településtől messze helyezkedik el, így a határellenőrzés Tiborszálláson történik meg, a román oldalon pedig Nagykárolyban. Jelenleg nemzetközi személyvonatok használják a vonalat, bár kihasználtsága messze nem elégíti ki a lehetséges igényeket. Naponta két vonatpár közlekedik Nagykároly és Mátészalka között. A vonal fejlesztésével interregionális kapcsolat lenne kiépíthető Ungvár-Csap-Záhony-Mátészalka-Nagykároly-Zilah útvonalon át.

A Nyírábrány-Érmihályfalva (Valea lui Mihai) vasúti határátmenet [lásd: 4] a nem villamosított Debrecen-Nyírábrány-Érmihályfalva fővonalon fekszik. A vonalat 1871-ben építették a Debrecen-Nagykároly-Szatmárnémeti vonal részeként. Érmihályfalvától Nagyvárad (Oradea) és Szatmárnémeti (Satu Mare) felé vannak csatlakozó vonatok. A DebrecenNyírábrány vonal a Debrecen környéki elővárosok közlekedését is biztosítja. Debrecen és Érmihályfalva között napi három vonatpár biztosítja a nemzetközi utasok számára az eljutási lehetőséget, két vonat egészen Nagyváradig, egy vonat pedig Szatmárnémetiig közlekedik. Ez az egy szerelvény viszont 2019. decemberi menetrendváltástól kezdve Szamos Eurocity néven közlekedik Bécs és Szatmárnémeti között Budapest, Püspökladány és Debrecen érintésével. A közvetlen járatból adódó előnyökből azonban sokat elvesz a határállomásokon eltöltött idő, ami mindkét oldalon 20-25 percet tesz ki. Egy megfelelő menetrendi struktúrával a nemzetközi forgalomban közlekedő vonatok összeköttethetők a Magyarországon közlekedő belföldi Intercity járatokkal Budapestre, Nyíregyházára, és Miskolcra.

A régió két központját alkotó Debrecen és Nagyvárad (Oradea) közötti közvetlen vasúti összeköttetést Biharpüspökinél a MÁV egykori nagyváradi vonalához csatlakozó Debrecen-Derecske-Nagykereki-Nagyszántó-Biharpüspöki vonal biztosította 1911-es megnyitásától kezdve. Az első világháború után a vonal 10 kilométeres Nagyszántó-Biharpüspöki része román területre került, de a román vasúttársaság nem indított itt vonatokat. 1940-től egy rövid, 4 éves időszakra ismét létezett a forgalom a vonalon, de a II. világháború után a pálya határon átmenő szakaszát elbontották a román oldalról. Jelenleg a Magyarországon meglévő vonalszakasz a MÁV 106-os számú vonalaként üzemel.

Az ezredforduló után egyre több elképzelés látott világot, amelyek célja a két régióközpont közti közvetlen vasúti kapcsolat újraépítése, illetve létrehozása volt, annak érdekében, hogy a régiók közötti kapcsolat még erősebb legyen. Ezek közül az elképzelések közül az egyik a [lásd: 6b] Nagykereki-Nagyszántó közötti szakasz visszaépítését célozta meg, visszaállítva az egykori eredeti állapotot. A két ország közötti személy és teherszállítás egyik legfontosabb kapuja a Biharkeresztes és Biharpüspöki közötti [lásd: 6b] vasúti összeköttetés. A helyi személyforgalom, a határ két oldalán élők kiszolgálása mellett ez a határátmenet biztosítja Nagy várad, Kolozsvár, Nagykároly és Szatmárnémeti európai hálózathoz való nagysebességú csatlakozását. A Tiszavidéki Vasúttársaság által építtetett Püspökladány-Nagyvárad közötti vasútvonalat 1858-ban adták át a forgalomnak. A vonalon a trianoni döntést követően is fenntartották a forgalmat. A vasúti forgalmat a villamosítás hiánya mellett több szúk keresztmetszet, lassújel is korlátozza. A 101-es számú Püspökladány-Biharkeresztes MÁV vonal rekonstrukciója és villamosítása a közeljövőben megkezdődik (Joó F. 2019). 
A román sajtó nem kis éllel tudósított, hogy a míg magyar oldalon a felújítás után „csak” 100 km/h sebességú egyvágányú, villamosított pálya fog rendelkezésre állni, addig Romániában a Biharpüspöki-Kolozsvár szakaszon $160 \mathrm{~km} / \mathrm{h}$ sebességre alkalmas, 88 km-en kétvágányú, villamosított pályát építenek (BĂRBULESCU, A. 2020).

A Debrecen-Nagyvárad közvetlen kapcsolat megteremtését célzó elképzelések közül több is kapcsolódik ehhez a vonalhoz. Ezek közül egyik a Nagykereki-Biharkeresztes kapcsolat kiépítése [lásd: 6a], a másik pedig a 106-os vonalon elhelyezkedő Derecske, valamint a 101-es vonalon elhelyezkedő Berettyóújfalu között vasúti pálya [lásd: 6c] építése.

A Dévaványa-Szeghalom-Körösharsány-Körösszeg (Cheresig)-Nagyvárad (Oradea) vonal határon átlépő Kótpuszta-Nagyvárad szakaszát 1887-ben a Bihar HÉV társaság építette. 1920 után az utasszállítás a határ mindkét oldalán múködött, de vonatok nem léptek át a határon. 1944 után Körösnagyharsány [lásd: 7] a magyar oldalon ismét végállomássá vált, és 1971-ben másodszor is lebontották a határmenti pályát. A román oldalon Körösszeg és Nagyvárad között a pálya jelenleg is járható. 1997-ben a személyszállítást leállították, 2013-ban újraindították, majd 2015-ben ismét leállították. 2013 és 2015 közötti időszakban a személyszállítást az Interregional Calatori magánvállalkozás végezte. A 127-es számú MÁV vasútvonalon Körösnagyharsány és Vésztő között a személyszállítás 2009 decemberétől megszűnt. Egy itt helyreállított vasúti összeköttetés elsősorban a kis települések közötti forgalom helyi igényeit tudná kielégíteni. Így a Nagyváradról induló vonatok bevonhatnák a területet Nagyvárad és környéke gazdasági életébe. 2012-ben a CBRP-HURO Európai Uniós Program keretében megvalósíthatósági tanulmány készült a vonal újjáélesztéséról.

A Békéscsaba-Nagyvárad vasútvonal egyvágányú, nem villamosított vasútvonal, amelyet az Alföld-Fiumei Vasúttársaság építtetett 1871-ben. Békéscsaba és Kötegyán közötti szakasz a MÁV 128-as vonalának részét képezi, a Kötegyán és Nagyszalonta (Salonta) közötti [lásd: 8] szakasz a CFR 311 besorolási számú vonalszakasz, a Nagyszalonta és Nagyvárad közti pálya a Temesvár-Arad-Nagyvárad (CFR 310) vasútvonalhoz tartozik. Jelenleg naponta három pár vonat közlekedik Békéscsaba és Nagyszalonta között. A vonal Békéscsaba és Gyula számára elővárosi vonal jelleggel is múködhetne, mivel mindkét város jelentős turisztikai és kulturális látványosságokkal rendelkezik. Érdemes lenne a vonatokat nemcsak Nagyszalontáig, hanem akár Nagyváradig is közlekedtetni, emellett interregonális közlekedési módként adná magát egy Nagyvárad-Gyula-Békéscsaba-SzegedSzabadka (Subotica) összeköttetés létrehozása.

A kötegyáni állomásról régebben nem csak Nagyszalonta felé indultak vonatok, Pusztahollód felé is kiágazott itt egy vasútvonal, a Mátrakörös-vidéki HÉV Részvénytársaság által építtetett, 1899-ben átadott Vésztő-Kötegyán-Pusztahollód vonal. Az első világháború után a Kötegyáni állomás érdekes szituációba került, mivel a békeszerződésben lefektetettek szerint az állomást a felvételi épület és az áruraktár között vágta volna félbe a határ, később határkorrekcióval Magyarország területén maradhatott. A határ jelenleg pontosan a Nagyszalonta felőli váltóknál található, így mozdonyos szerelvény körül járásakor át kell mennie a mozdonynak Romániába.

A két ország közti vasúti összeköttetés legfontosabb verőere a kétvágányú, villamosított Budapest-Szolnok-Békéscsaba-Lőkösháza-(Kürtös)-Arad vasútvonal. A határátkelés Lökösháza és Kürtös (Curtici) között történik meg. A vasútvonal Szajol és Arad közti szakaszát a Tiszavidéki Vasúttársaság építtette, üzembehelyezése 1858-ban történt meg. A vonal 1920, majd 1945 után kettészakadt, a magyar oldalon a MÁV 120-as vonalaként, a román oldalon a CFR 200-as fővonalának részeként múködik. A Szajol-Lökösháza vonalszakasz villamosítása 1974-ben történt meg. Ez a vonal biztosítja a két ország közti teher és személyforgalom döntő részét. 
Az Aradi és Csanádi Egyesült Vasutak és előd vasútjai (Arad-Körösvölgyi Vasút és az Arad-Csanádi Vasút) a helyiérdekú vasutak első sikeres hazai példájának tekinthetőek. A társaság vasútvonalai behálózták Arad, Csanád és Békés vármegyét. Első vonaluk az Arad-Borosjenő 58 kilométer hosszúságú vonal volt, amelyen 1877-től szállítottak árukat és utasokat.

Az I. világháború után a vasúttársaság vonalainak kétharmada román területre került. Magyarország területén maradtak a Szőreg-Mezőhegyes-Kétegyháza, a MezőhegyesBattonya és Kétegyháza-Elek vonalszakaszok, valamint az AEGV teljes hálózata. A határ Elek és Ottlaka [10], illetve Battonya és Ópécska [lásd: 11] között metszette a társaság vonalait. A vasúti pályát mindkét határon átmenő vonalnál felbontották, így a határon átmenő forgalom mindkét szakaszon megszúnt. A Kétegyháza és Elek közti rövid szakasz az 1968-as közlekedéspolitikai koncepció bezárásra ítélte, ám a román oldalon Ottlakára továbbra is járnak vonatok. Pécska (Pecica) és Battonya között a vasúti határforgalom 1944-ig múködött. Battonyától az országhatárig vezető szakaszt 1978-ban szedték fel. Újabban a magyar-román kistérségi együttmúködés során egyre hangsúlyozottabban vetôdik fel az Elek-Ottlaka, illetve a Battonya-Pécska közötti vasútvonal újranyitása, ám ennek megvalósulására jelenleg minimális esély mutatkozik.

A Hódmezővásárhely-Makó-Nagyszentmiklósi HÉV vonala a MÁV 130 számú Szolnok-Hódmezővásárhely-Makó-vasútvonalának részeként épült 1903-ban. Az I. világháború után az Apátfalva-Csanád [lásd: 12] közötti összeköttetés is megszúnt.

Románia számos, egymástól különböző kultúra és korszak néhol viharos, de mégis érdekes összképet adó együttese, amelyekhez a hátteret sziklás folyóvölgyek és fenyvesekkel díszített hegycsúcsok szolgáltatják. Különösen igaz ez Erdélyre, amelyet négy nép és négy vallás formált mai képére, illetve a magyar történelem és múvészet legnagyobbjainak emlékét őrzi Mátyás királytól Tamási Áronig. Románia érdekes, lenyűgözô úti célt szolgál minden turistának, zarándoknak stb. (2. ábra). Amint GroTTE J. (2013) cikkében

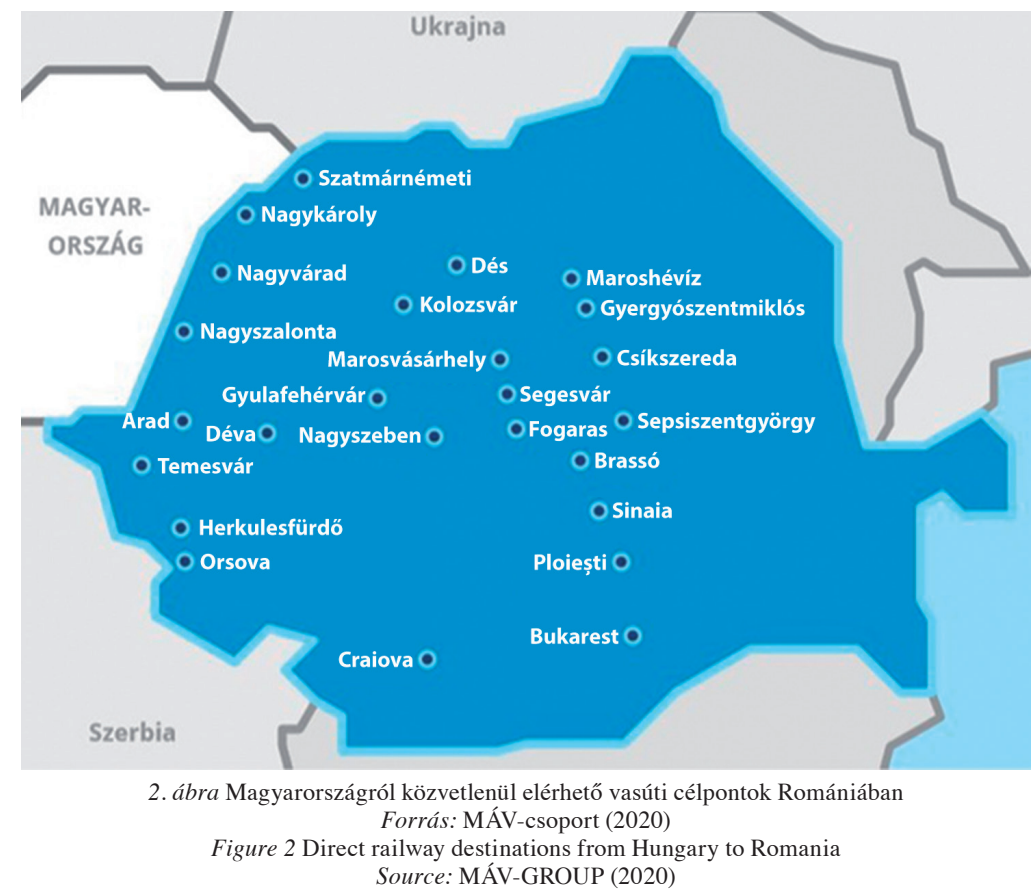


megemlíti, a változó gazdaságok, társadalmak vonzó célpont lehetnek a „fapados” turisták számára. STANCIU S.M. et al. (2011) szerint a nagyon sok turisztikai desztinációval rendelkező területeknek rendelkezniük kell az infrastruktúra fejlesztéséhez szükséges fejlesztési lehetőségekkel. Tóтн G. et al. (2014) kutatásában leírja, hogy a közlekedé- si elérhetőség számos ország számára fontos tényező a vendégéjszakák alakulásában. SOMOGYi B. (2011) tanulmánya szerint: „Egy megfelelően rendben tartott városkaput látva az érkező utasban nagyobb fokú elégedettségérzet alakul ki, ami a turisztikai költés növekedésében ölthet testet."

A két ország közti vasúti közlekedés fejlesztésének nem csak közlekedéspolitikai aspektusai vannak. Bár ebben a régióban nem jelenik meg olyan mértékú ingázás, mint a Nyugat-Dunántúl régió és Ausztria keleti tartományai (Burgenland, Stájerország, AlsóAusztria és Bécs) között, a rendelkezésre álló magyarországi statisztikai adatok alapján a két ország között szignifikánsan megjelent a hivatásforgalmi ingázás is.

A KSH (2015), EGEDY T. (2017), valamint DAJNOKI és szerzőtársai (2020) tanulmányaikban kimutatták, hogy az elmúlt időszakban a Romániában munkát vállaló magyar állampolgárok száma növekedett. A 2011-es népszámlálás adatai alapján ez a szám meghaladta a másfélezret. A térségben megfigyelheto, hogy több, a magyar-román határhoz közel fekvő nagyváros, mint például Nagyvárad, Szatmárnémeti és Arad urbanizációs vonzáskörzete átterjed Magyarországra, így például román állampolgárok vásárolnak olcsóbb magyarországi ingatlant a határ közelében, és munkájukat továbbra is Romániában tartják fent. Ebben fontos szerepet játszhatnak a kialakuló eurorégiók, mint a Kárpátok Eurorégió vagy a Hajdú-Bihar-Bihor Eurorégió, amelyek eredményesen múködhetnek közre a geopolitikai helyzet javításán, a gazdasági kapcsolatok fejlesztése érdekében (SÜLI-ZAKAR I. 2009).

Magyarország és Románia kapcsolatában nagyon jelentős a szerepe a külkereskedelemnek és a befektetôi kapcsolatoknak, amelyet jól tetten érhető a nagyvállalatok markáns jelenlétében egymásnál. A nagy magyar „blue chip” vállalatok (pl. Mol, OTP, Richter Gedeon) pozíciója erős a romániai piacon, 2017. évi adatok szerint mintegy 12 ezer magyar tőkével múködő vállalkozás múködik Romániában. A Magyarországon talán nem annyira látványos a romániai befektetők jelenléte, de például a legjelentősebb a médiaszolgáltatási szektorban erős pozíciót magáénak tudó DIGI romániai tulajdonosa (RCS\&RDS SA) (HORVÁTH. 2018).

Az alapvetően kedvező kétoldalú kapcsolatok további fejlesztésének céljain túl - tágabb kontextusban - az Európai Unió a tagállamok közötti európai közlekedési hálózat létrehozását túzte ki célul, amely egyúttal összekapcsolja majd az Európai Uniót a szomszédos országokkal és a világ többi részével, a növekedés és a versenyképesség előmozdítása érdekében. Ez a multimodális ún. TEN-T törzshálózat kilenc fő közlekedési folyosót foglal magában, amely összeköttetést hoz létre kelet és nyugat között.

A vizsgálat tárgyát képező két ország infrastrukturális hálózatai a TEN-T hálózat két folyosóján keresztül csatlakoznak egymáshoz (3. ábra) (EC 2020a, b):

A Keleti/Kelet-mediterrán folyosó a németországi Bréma, Hamburg és Rostock kikötőitől halad Csehországon és Szlovákián át - egy Ausztrián, majd Magyarországon át a romániai Constanța kikötőjéig nyúló ággal - a bulgáriai Burgasz kikötőjéig, összeköttetéssel Törökország és a görögországi Szaloniki és Pireusz kikötői felé, valamint „tengeri autópálya" útján összeköttetést kínálva Ciprussal. A folyosót vasútvonalak, közutak, repülőterek, kikötők és vasúti-közúti terminálok alkotják, és az Elba folyó belvízi útja is a részét képezi. A legjelentősebb szúk keresztmetszetet a Temesvár és Szófia közötti vasúti szakasz jelenti.

A Rajna-Duna folyosó két dél-németországi, párhuzamosan futó tengely útján (az egyik a Majna és a Duna mentén, a másik Stuttgarton és Münchenen át halad, és egy ága Prágán 
és Zsolnán át elnyúlik a szlovák-ukrán határig) köti össze Strasbourgot és Mannheimot Ausztrián, Szlovákián és Magyarországon át a romániai Constanța és Galati kikötőivel. A folyosót vasútvonalak, közutak, repülőterek, kikötők és vasúti-közúti terminálok alkotják, és részét képezi a Majna és a Majna-Duna-csatorna belvízi útjainak rendszere, a Duna Kelheim alatti teljes szakasza, valamint a Száva folyó is. A kulcsfontosságú projektek: a szúk keresztmetszetek megszüntetése a belvízi utak és a Stuttgart-Ulm és MünchenFreilassing közötti vasúti szakaszok mentén.

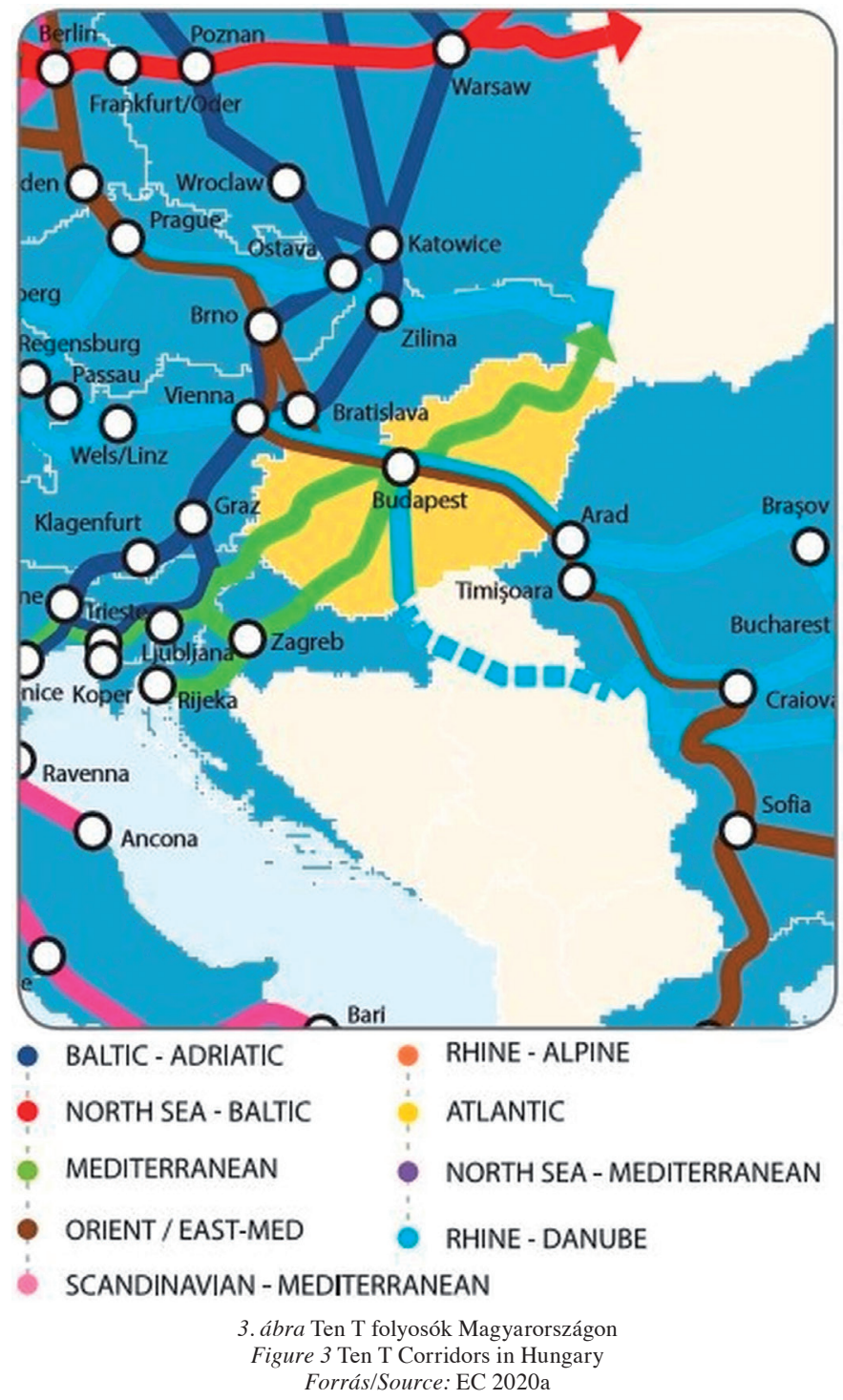

A 2. táblázat foglalja össze a két ország egyes folyosóinak vasúti projektjeit és az ahhoz kapcsolódó tevékenységeket. 
Vasúti projektek Magyarországon és Romániában

Rail projects in Hungary and in Romania

\begin{tabular}{|c|c|c|c|}
\hline Vonal & Projekt tevékenység & Magyarország & Románia \\
\hline $\begin{array}{l}\text { Rijeka-Zágráb } \\
\text {-Budapest }\end{array}$ & $\begin{array}{l}\text { Mediterrán folyosó } \\
\text { tanulmányok és munkálatok } \\
\text { (ideértve egy új pálya építését és } \\
\text { egy második pálya építését } \\
\text { Rijeka és a magyar határ között) }\end{array}$ & $\mathrm{X}$ & - \\
\hline Pragersko-Zalalövő & $\begin{array}{l}\text { határon átnyúló szakasz: } \\
\text { tanulmányok, a munkálatokat } \\
2020 \text { előtt meg kell kezdeni }\end{array}$ & $\mathrm{X}$ & - \\
\hline Boba-Székesfehérvár & korszerûsítés & $\mathrm{X}$ & - \\
\hline $\begin{array}{l}\text { Budapest-Miskolc } \\
\text {-ukrán határ }\end{array}$ & korszerűsítés & $\mathrm{X}$ & - \\
\hline Pozsony-Hegyeshalom & $\begin{array}{l}\text { Keleti/kelet-mediterrán folyosó } \\
\text { határon átnyúló szakasz, } \\
\text { korszerűsítés }\end{array}$ & $\mathrm{X}$ & - \\
\hline Tata-Biatorbágy & korszerüsítés & $\mathrm{X}$ & - \\
\hline $\begin{array}{l}\text { Budapest-Arad } \\
\text {-Temesvár-Calafat }\end{array}$ & $\begin{array}{l}\text { korszerúsítés Mo-n befejezéshez } \\
\text { közel, Romániában folyamatban }\end{array}$ & $\mathrm{X}$ & $\mathrm{X}$ \\
\hline $\begin{array}{l}\text { Vidin-Szófia-Burgas } \\
\text { /TR határ } \\
\text { Szófia-Thessaloniki } \\
\text {-Athén/Pireusz }\end{array}$ & $\begin{array}{l}\text { tanulmányok és munkálatok: } \\
\text { Vidin-Sofia-Thessaloniki } \\
\text {-Athens; korszerúsítés: } \\
\text { Szófia-Burgas/TR határ }\end{array}$ & - & $\mathrm{X}$ \\
\hline $\begin{array}{l}\text { Bécs-Pozsony } \\
\text { /Bécs-Budapest } \\
\text { /Pozsony-Budapest }\end{array}$ & $\begin{array}{l}\text { Rajna-Duna folyosó } \\
\text { nagy sebességú vasútvonalra } \\
\text { vonatkozó tanulmányok }\end{array}$ & $\mathrm{X}$ & \\
\hline Budapest-Arad & $\begin{array}{l}\text { Budapest és Arad közötti nagy } \\
\text { sebességú hálózatra vonatkozó } \\
\text { tanulmányok }\end{array}$ & $\mathrm{X}$ & $\mathrm{X}$ \\
\hline $\begin{array}{l}\text { Arad-Brassó-Bukarest } \\
\text {-Constanta }\end{array}$ & $\begin{array}{l}\text { egyes szakaszok korszerúsítése; } \\
\text { nagy sebességú vasútvonalra } \\
\text { vonatkozó tanulmányok }\end{array}$ & $\mathrm{X}$ & $\mathrm{X}$ \\
\hline Craiova-Bukarest & tanulmányok és munkálatok & $\mathrm{X}$ & $\mathrm{X}$ \\
\hline
\end{tabular}

Forrás/Source: EC 2020a,b

A vasúti közlekedésnek már a megjelenésekor is jelentős szerepe volt az európai katonapolitika alakulásában. Ezt megfigyelhettük az első világháború utáni határkialakításnál is. A legfrissebb hírekben is megfigyelhetjük a katonapolitika ilyen jellegú megjelenését Romániában és a régióban. 2018-ban jelent meg a Rail-2-Sea kezdeményezés, amely a Gdansk-i és a Constanta-i kikötő vasúti összeköttetését hívatott létrehozni Lengyelország, Szlovákia, Magyarország és Románia érintésével. 2020 októberében Románia támogatási együttmúködést írt alá az USA-val (MUTLER, A. 2020) a projekt finanszírozására, amely 
során mind a kereskedelmi, mind a katonai célú (NATO) szállítmányok használhatnák a modernizált pályát.

Már a 2000-es évek elején megjelentek olyan elképzelések, amelyek a TEN-T folyosók fejlesztéséhez kapcsolódóan egy Párizs-Bécs-Budapest-Bukarest-Constanta vasúti folyosó részeként megépülhetne egy Budapest- Bukarest-Constanta nagysebességú vasúti kapcsolat, és ez a gondolat 4-5 évente újra és újra előkerül. A román és a magyar közlekedési minisztérium képviselői a 2007. novemberi nagyszebeni közös kormányülés keretében írták alá a megállapodást a nagy sebességű, az európai vasúti közlekedési hálózathoz kapcsolódó vasútvonal jövőbeni megvalósításáról a Budapest-Bukarest-Konstanca vonalon, majd 2012-ben a Román Vasúttársaság (CFR) jelentette be, hogy előkészíti a dokumentációt a Romániát átszelő nagysebességú vasút előzetes megvalósíthatósági tanulmányának elkészítéséról szóló pályázathoz (IHO 2012). 2018 elején jelentek meg a magyar (MFOR 2018) és román (MoNiTURUL 2018) sajtóban a két ország külügyminisztereinek közös szándéknyilatkozatáról szóló hírek, melyek szerint a magyar kormány 1 milliárd forinttal támogatja Budapest és Kolozsvár (Cluj-Napoca) közötti nagysebességú vasúti összeköttetésének megvalósíthatósági tanulmányának elkészítését. 2020 januárjában megjelent a tanulmányról szóló közbeszerzési értesítő (MAGYARÉPÍTŐK 2020).

A SEESARI (Délkelet-Európa Stratégiai Vasúti Innovációs Szövetség) elképzelései szerint egy nagysebességú vasúti hálózat/öv fejleszthető ki a Duna régióban (BécsLjubljana-Zágráb-Belgrád-Budapest-Pozsony-Bécs) (4 a ábra) (Verlic, P.-JEMEnSEK, B. 2018). Ez a vasúti hálózat 6 fóvárost, és annak 9 millió lakosát kapcsolná össze az érintett 6 országgal és annak 28 millió lakosával. A Bécs-Graz-Villach és Belgrád-Budapest vasútvonalak már építés alatt állnak. A vasúti hálózat teljes hossza $1500 \mathrm{~km}$ lenne, lehetséges északnyugati és délkelet-európai kapcsolatokkal. A Duna régió remélhető vasúti forradalmának fontos alapeleme a regionális vasútvonalak újjáélesztése, melynek jelentősége legfóképpen abban van, hogy az alapinfrastruktúra már létezik, alacsony kihasználtságú vonalakból áll, és kevésbé fejlett, elhanyagolt területeket kapcsolna be a vasút európai hálózatába.

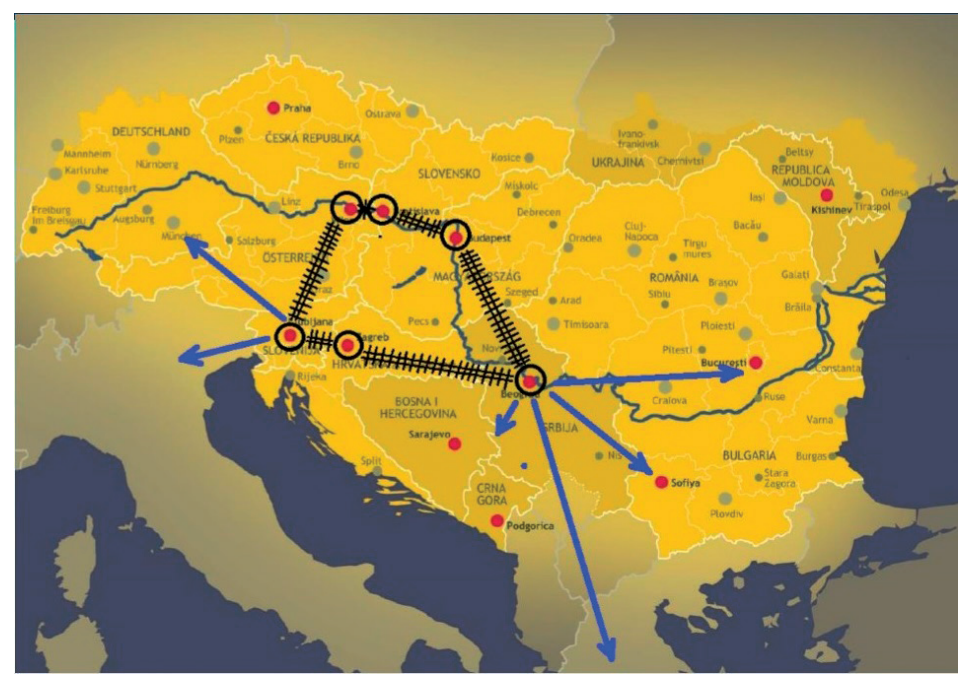

4. ábra A Duna régió elképzelt nagysebességû vasúti hálózata Figure 4 High Speed Rail Network in Danube Region Forrás/Source: VerLic, P.-JEMENSEK, B. 2018 


\section{Összefoglalás és következtetések}

A vizsgált két országban a vasút szerepe továbbra is jelentős a személyszállításban. Egy új, határokon átnyúló közlekedési kapcsolatot mind a helyi és regionális szintű hatóságoknak, mind a civil szférának támogatni szükséges. Minimum három évre van szükség ahhoz, hogy a bevezetett szolgáltatás bebizonyítsa létjogosultságát.

A viteldíjaknak és a szolgáltatásoknak vonzónak és egyszerúnek kell lenniük. Ez különösen igaz, ha különböző nyelvet és eltérő valutát használnak a határ két oldalán. Erre például a zónás megoldás jó megoldás lehet. A határ túloldalán lévő városba szóló jegyeknek a helyi közlekedés használatát is magába kell foglalnia.

Az Európai Unió országaiban jól megfigyelhető, hogy az ingázás (commuting) és a turizmus is egyre nagyobb szerepet tölt be az emberek mindennapi életében (EUROBAROMETER 2018). A mai kor színvonalának megfelelő, korszerú infrastruktúra és magas szintú szolgáltatás fejlesztésével környezetbarát, fenntartható munkába járási, turisztikai lehetőséget lehetne nyújtani a határ két oldalán lakók számára.

A kötöttpályás közlekedés területén a szomszédos országok közötti forgalom fenntartásához a szomszédos államok együttmúködése szükséges. Az eltérő múszaki szabályozásokhoz való viszonosságon alapuló kölcsönös megállapodások szükségesek ahhoz, hogy a kötöttpályás jármú a szomszédos ország pályáit használhassa. A két ország közti vasúti közlekedés fejlesztése mindkét ország számára létfontosságú.

Ez a fejlesztés több irányba is elindulhat:

- Egyrészt az interregionális együttmúködés keretei között (munkaerőpiac, beruházások stb.), a határ menti térségekben a kapcsolatok fejlesztésével.

- Másrészt a meglevő vonalak felújításával, modernizációjával „európai színvonalú” kapcsolat kialakításával.

- Harmadrészt az egyelőre még csak elképzelésként felmerülő Budapest-Kolozsvár (-Bukarest) nagysebességú vasút kiépítésével.

Magyarország és Románia az utóbbi években erősödő gazdasági együttmúködése, valamint az utasforgalom igényei mindenképpen indokolják a két ország közti közlekedési kapcsolatok számottevő - mennyiségi és minőségi - fejlesztését. Amennyiben a tervezett fejlesztések, beleértve a Budapestet Kolozsvárral összekötő gyorsvasút megépül, az számottevően megkönnyítené a közlekedést, vonzóbbá tenné és növelné a két ország közti turizmust és a rokoni-baráti kapcsolatok ápolását, mindennek multiplikátor hatása lehet a helyi gazdaságra. Különösen így lenne ez, amennyiben a gyorsvasút egészen Bukarestig megépülne, hiszen magyar szemmel ez egyúttal a Kolozsváron túli erdélyi települések jobb megközelítését is lehetővé tenné, hiszen a gyorsvasút bizonyára megállna Marosvásárhelyen, Brassóban és más nagyobb településeken. Bukaresti nézőpontból is kétségtelen előnye lenne az erdélyi települések és természetesen Budapest, illetve más magyar városok jobb megközelíthetôségének.

A gyorsvasúti projekt megvalósulása esetén is nagyon fontos szerepe van a két országot összekapcsoló hagyományos vasúti pályák korszerűsítésének, illetve a vasúti logisztikai együttmúködésnek, amelyek nemcsak Erdély belső településeinek elérhetőségét, hanem a határ menti kapcsolatok fejlesztését is jobban tudnák segíteni.

A határon átmenő forgalom fejlesztése mind az országok, mind a kisebb-nagyobb régiók számára fontos előnyöket hordozhat. Ennek különleges aktualitást kölcsönöz, hogy 2021 az vasút európai éve, amely lehetőséget teremthet a tanulmányban említett tervek megvalósításának elindításában, valamint egy biztonságosabb, vonzóbb, fenntarthatóbb és zöldebb közlekedési kapcsolat fejlesztésében Magyarország és Románia számára. 
A javuló közlekedési feltételek nyilvánvalóan éreztetik majd hatásukat a tovább bővülő külkereskedelemi és befektetői kapcsolatokban, a helyi-regionális szintú gazdaság fejlődésben és az idegenforgalomban. Mindez hosszabb távon elvezethet a mainál is intenzívebb és kiegyensúlyozottabban fejlődő kapcsolatokhoz a két ország között, és segíthet a történelmi múlt nehéz örökségén való felülemelkedésben és a kölcsönös bizalom erősítésében a magyar és román nemzet között.

\section{ERdEINÉ KÉSMÁRKI-GALlY SZILVIA}

Budapesti Metropolitan Egyetem ÜKT Kar, Üzleti Tudományok Intézete, Budapest sgally@metropolitan.hu

ERdEI ATtila

SZIE Gazdaság- és Regionális Tudományok Doktori Iskola, Gödöllő erdei1974attila@gmail.com

NESZMÉLYI GYÖRGY IVÁN

BGE KVIK Kereskedelem Tanszék, Budapest

Neszmelyi.Gyorgy@uni-bge.hu

\section{IRODALOM}

BĂRBUlESCU, A. 2020: Ce investiții feroviare sunt prevăzute în planul de relansare economică al Guvernului Orban. - https://clubferoviar.ro/planul-de-relansare-economica/ [Letöltés: 2020.11.15.].

DAJNOKi K.-Sipos N.-HÉDER-RimA M.-KôMíves P. M. 2020: Mobilitás a határmenti régiókban - Románia. - Pécsi Munkajogi Közlemények XIII. Különszám. pp. 101-128.

DRKE 2011: A közösségi kapcsolatok fejlesztésének lehetőségei Magyarország keleti határszakaszán, különös tekintettel a Debrecen-Nagyvárad közvetlen vasúti kapcsolat helyreállíthatóságára. - NCA, Debrecen, 22 p.

EC 2011: White Paper on transport. - https://ec.europa.eu/transport/sites/transport/files/themes/strategies/ doc/2011_white_paper/white-paper-illustrated-brochure_en.pdf [Letöltés: 2020.04.09.].

EC 2020a: Hungary. European Commission. - https://ec.europa.eu/transport/sites/transport/files/tent_hu.pdf [Letöltés: 2020.04.15.].

EC 2020b: Romania. European Comission. - https://ec.europa.eu/transport/sites/transport/files/ten-t-countryfiches/ten-t-country-fiches-ro_en.pdf [Letöltés: 2020.04.15.].

EGEDY T. 2017: A külföldre ingázás statisztikai, demográfiai és területi jellemzői Magyarországon. - Területi Statisztika, 2017, 57 (4): pp. 385-405.

EUROBAROMETER 2018: Europeans' satisfaction with passenger rail services. European Commission, September 2018, - https://utk.gov.pl/download/1/45607/f1463en.pdf [Letöltés: 2020.12.03.].

Grotte, J. 2013: Budget Tourism - Transition Economy. - International Journal of Business Insights and Transformation, 6. 2. pp. 104-109.

HAJDÚ Z. 2019: Magyarország történeti államföldrajza: Korszakonként változó államterület, határtörténet és határpolitika. - Dialóg Campus, Budapest. 304 p.

HARdi T.-HAJdú Z.-MEZEI I. 2009: Határok és városok a Kárpát-medencében. - MTA RKK Győr-Pécs. 375 p.

HoRvÁth, A. Cs. (2018): Románia szomszédos országokkal folytatott külgazdasági kapcsolatainak jellemzői KKI-elemzések, Külügyi és Külgazdasági Intézet, 2018 https://kki.hu/assets/upload/21_KKI-elemzes_ROU_Horvath_20180611.pdf [Letöltés: 2020.12.03.].

HoRvÁth Cs. S. 2016: A vasút funkciói és hatásai Magyarországon 1920-ig. pp. 81-96. - In HoRváth Cs. S. et al. (szerk.): Ezerarcú vasút. Vasút - történet - írás. Budapest - Magyar Vasúttörténeti Park Alapítvány, Virágmandula Kiadó Kft., Pécs. 323 p.

IHO 2012: Gyorsvasút kötné össze Budapestet Konstancával. - https://iho.hu/hirek/gyorsvasut-kotne-ossze-budapestet-konstancaval-120217 [Letöltés: 2020.12.01.].

Joó, F. 2019: Hungary - Romania line to be electrified. - International Railway Journal. - https://www.railjournal.com/regions/europe/hungary-romania-line-to-be-electrified [Letöltés: 2020.11.15.].

KÖLLER L. 2003: A különböző vasúti hálózatok vonali és hálózati hatékonysága, illetve a versenyképesség értelmezése a vasútnál hazai tapasztalatok és nemzetközi példák alapján. - http://www.vki.hu/ tfleisch/ haver/ szakirodalom/haver-KOLLER-vasut.pdf [Letöltés: 2019.01.03.]. 
KSH 2015: Ingázás a határ mentén. - https://www.ksh.hu/docs/hun/xftp/idoszaki/regiok/gyoringazas.pdf [Letöltés: 2020.11.15.].

MAGYARÉPÍTŐK 2020: Szupergyors vasúti közlekedés épülhet ki Budapest és Kolozsvár között. - https:// magyarepitok.hu/vasutfejlesztes/2020/01/szupergyors-vasuti-kozlekedes-epulhet-ki-budapest-es-kolozsvar-kozott [Letöltés: 2020.11.25.].

MAJdÁn J. 2001: A vasút szerepe a határok kialakulásában. - Rubicon, 8-9. pp. 63-67.

MAJdÁn J. 2010: Mi veszett el Trianonban? - Honismeret, 38 (5), pp. 31-35. - https://epa.oszk.hu/03000/03018 /00220/pdf/EPA03018_honismeret_2010_05_031-035.pdf [Letöltés: 2020.11.15.].

MÁV-csoport 2020: Románia. - https://www.mavcsoport.hu/mav-start/nemzetkozi-utazas/romania [Letöltés: 2020.04.13.].

MFOR 2018: Itt a döntés: jöhet a Budapest-Kolozsvár gyorsvasút. - https://mfor.hu/cikkek/makro/itt-a-dontes-johet-a-budapest-kolozsvar-gyorsvasut.html [Letöltés: 2020.11.23.].

Miszlay Zs. 2009: Magyarország vasúthálózata Trianon tükrében. - A Virtuális Intézet Közép-Európa Kutatására (VIKEK) Évkönyve 1 (1) pp. 274-279.

MoNitURUL 2018: România şi Ungaria vor construi o cale ferată de mare viteză între Cluj şi Budapesta. - http:// www.monitorulcj.ro/actualitate/62292-romania-si-ungaria-vor-construi-o-cale-ferata-de-mare-viteza-intre-cluj-si-budapesta [Letöltés: 2020.11.23.].

MutLER, A. 2020: Rail-2-Sea and Via Carpathia, the US-backed highway and rail links from the Baltic to the Black Sea.- https://universul.net/rail-2-sea-and-via-carpathia-the-us-backed-highway-and-rail-links-fromthe-baltic-to-the-black-sea/ [Letöltés: 2020.11.15.].

RAYMOND, G. 2017: A recent history of passenger train operators in Romania. - http://www.railweb.ch/en/a-recent-history-of-passenger-train-operators-in-romania/ [Letöltés: 2020.04.03.].

Somogyi B. 2011: A vasút szerepe a hazai vasúti csomópontok turisztikai miliőjében. - Földrajzi Közlemények 135. 4. pp. 431-443.

Somogyi B.-Michalkó G. 2016: A regisztrált láthatatlanok: az időskorúak vasúti utazási magatartásának vizsgálata Magyarországon. -Földrajzi Közlemények 140. 1. pp. 41-54.

StAnciU, S.M.-FeHER, A.-TABĂRĂ-AmÂnAR, G.C. (2011), Analysis of new law on tourism in Romania and its implications on our economy. - Lucrări Ştiinţifice, SERIA I, XIII (4), pp. 259-266. -https://usab-tm. ro/utilizatori/management/file/cercetare/2010-2011/vol_xiii/section4/tour037.pdf [Letöltés: 2020.04.15.].

SÜLI-ZAKAR I. 2009: A határok és a határon átnyúló kapcsolatok átértékelődése Kelet-Közép-Európában. - In: Közép-Európai Közlemények, 2.4-5. 6-7. pp. 137-144.

SÜLI-ZAKAR, I.-KECSKÉs, T. 2015: The historical borders and the cross-border connections' effect on Debrecen's spirituality and cultural economy. Eurolimes, 19. pp. 99-116.

TóTH G.-DÁVID L.-VASA L. 2012: A közlekedés szerepe az európai turisztikai áramlásokban. - Területi Statisztika, 15. 2. pp. 160-176.

Tóth, G.-DÁvid, L.-VASA, L. 2014: The role of transport in European tourism flows. - Acta Geographica Slovenica, 54. 2. pp. 311-320.

TuRnock, D. 2004: Railway network development in inter-war Romania: Economic and strategic motives. - Geographica Pannonica 8. pp. 16-24. - http://www.dgt.uns.ac.rs/dokumentacija/pannonica/papers/volume08_03.pdf [Letöltés: 2020.11.15.].

TuRnock, D. 2005: Romania's railway development 1950-1989: Changing priorities for socialist construction. - Geographica Pannonica, 9. pp. 32-43. -http://www.dgt.uns.ac.rs/dokumentacija/pannonica/papers/volume09_07.pdf [Letöltés: 2020.11.15.].

VAsA, L.-RAdulescu, A. 2019: The Romanian Economy - Recent Developments and Prospects. - KKI Elemzések, 41. pp. 1-12.

VERLIC, P.-JEMENSEK, B. 2018: Connecting Danube region by rail-improved passenger services and infrastructure development opportunities. -https://transport.danube-region.eu/wp-content/uploads/sites/2/2019/09/ S4-7_Danube2018_BJemensek.pdf [Letöltés: 2020.04.15.]. 